\title{
Arsenicum
}

\section{Sobre o Livro}

Após o emblemático O Bairro da Tabela Periódica Periódica, peça bandeira das celebrações de 2019 do Ano Internacional da Tabela Periódica, Manuel João Monte volta agora numa peça dedicada a um dos apartamentos do condomínio do bairro que nos apresentou em 2019.

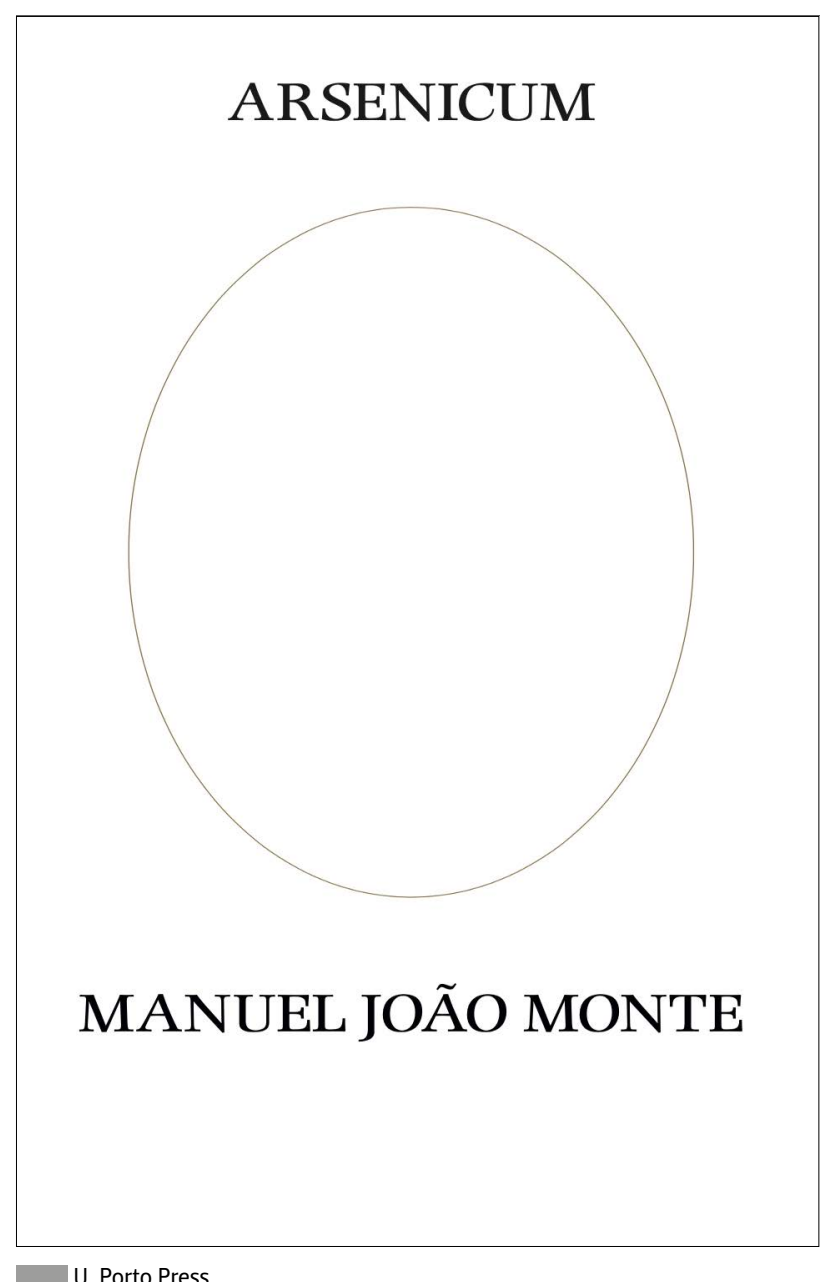

ISBN: 978-989-746-260-3

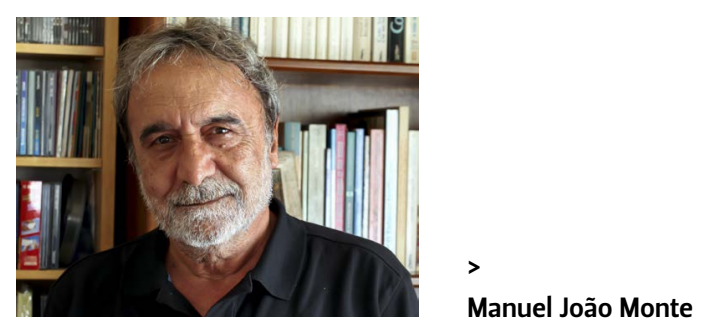

"Manuel João Monte já nos tinha deliciado com uma excelente e divertida peça de teatro, O Bairro da Tabela Periódica, em que a Tabela Periódica aparece como um condomínio de apartamentos ocupados pelos diversos elementos químicos e onde não falta sequer uma referência a esse conflito de género hoje tão na moda com o "me too". E, voltando a escrever sobre a Quoisa, propõe agora uma nova peça teatral em que começa a entrar num dos apartamentos do condomínio, ocupado pelo Arsénio que, conjuntamente com o Mercúrio, o Chumbo, o Antimónio e o Tálio foi largamente utilizado como veneno, tendo assumido proporções de quase epidemia devido às dificuldades, então ainda não resolvidas, da sua deteção eficaz. Confesso que me diverti e espero que essa seja a sensação de todos quantos lerem este texto de João Monte ou assistam a uma representação da nova peça”.

Alberto Amara

\section{Sobre o Autor}

Manuel João Monte é Professor Associado Jubilado do Departamento de Química e Bioquímica da Faculdade de Ciências da Universidade do Porto. É membro integrado do grupo de investigação em Termodinâmica Molecular e Supramolecular do Centro de Investigação em Química da UP (CIQUP), tendo publicado mais de 100 artigos em revistas científicas internacionais. Traduziu para português as peças de "Ciência-no-Teatro" Oxigénio de Carl Djerassi e Roald Hoffmann e Falácia de Carl Djerassi, editadas pela U. Porto Press e levadas à cena, respetivamente, em 2006 e 2011, pela companhia Seiva Trupe, no Teatro do Campo Alegre. Publicou, em 2019, na coleção Fora de Série da U. Porto Press, O Bairro da Tabela Periódica também patrocinado pela SPQ. 